\title{
Application of a bioeconomic model for supporting the management process of the small pelagic fishery in the Veneto Region, northern Adriatic Sea, Italy
}

\author{
SILVIA SILVESTRI ${ }^{1}$ and FRANCESC MAYNOU ${ }^{2}$ \\ ${ }^{1}$ Dipartimento di Scienze Economiche, Università Ca' foscari, Cannaregio Fond.ta S. Giobbe 873, 30121 Venice, Italy. \\ E-mail: silvia.silvestri@unive.it \\ ${ }^{2}$ Institut de Ciènces del Mar (CSIC), Psg. Marítim de la Barceloneta, 37-49, 08003 Barcelona, Spain.
}

\begin{abstract}
SUMMARY: We explore the sustainability of the small pelagics fishery in the northern Adriatic sea, northeastern Italy, by means of a bioeconomic simulation model. This model reproduces the biological and economic conditions in which the fisheries occur. Starting from an initial condition (2004), the simulation model incorporates the biological and economic processes of the resources and the fishing fleet and computes the most probable future trajectory of the system under different management conditions. We analysed the projection of selected indicators (biomass, recruitment, catches, profits) under four different management scenarios based on effort control, and we assessed the performance of these management measures against the current situation. The four scenarios were: $i$ ) increase in fuel price, ii) reduction in fuel price, iii) limiting the number of days at sea, and $i v$ ) extending the fishing period. Each management event was introduced in the third year of the simulation. For each scenario a stochastic simulation was carried out. Our results show that the impact of each management measure tested was not homogeneous across the fleet. In particular, comparatively smaller vessels generally display narrower profit margins and tend to be more sensitive to negative shocks, reinforcing the idea that management measures should be calibrated by stratifying the fleet before implementation.
\end{abstract}

Keywords: Northern Adriatic, bioeconomic model, small pelagics, sardine, anchovy, mid-water pair trawl.

\begin{abstract}
RESUMEN: APLICACIÓN DE UN MODELO BIOECONÓMICO DE APOYO A LA GESTIÓN DE LA PESQUERÍA DE PEQUEÑOS PELÁGICOS EN LA REgión DEl VéNeto, AdRiático nORTE, ITAlia. - Exploramos la sostenibilidad de la pesca de pequeños pelágicos en el Adriático norte, Italia nor-oriental, mediante un modelo bioeconómico de simulación. El modelo reproduce las condiciones biológicas y económicas en las que operan las pesquerías. A partir de una situación inicial (2004), el modelo de simulación incorpora los procesos biológicos y económicos de los recursos y de las flotas pesqueras y permite calcular las trayectorias futuras más probables del sistema bajo distintas condiciones de gestión. Analizamos la proyección de indicadores seleccionados (biomasa, reclutamiento, capturas, beneficios) bajo cuatro escenarios de gestión diferentes, basados en el control del esfuerzo, y evaluamos los resultados de estas medidas de gestión frente a la situación actual. Los cuatros escenarios fueron: $i$ ) aumento del precio del carburante, ii) reducción del precio del carburante, iii) limitación del número de días de pesca, y $i v$ ) extensión del período de pesca. Los eventos se introdujeron en el tercer año de la simulación. Los resultados muestran que cada medida tiene un impacto que no es homogéneo para toda la flota, en particular, los barcos más pequeños muestran generalmente margen de beneficios más bajos y tienden a ser más sensibles a los shocks negativos, de manera que es necesario calibrar las medidas de gestión estratificando la flota antes de su implementación.
\end{abstract}

Palabras clave: Adriático Norte, modelo bioeconómico, pequeños pelágicos, sardina, anchoa, red pelágica de arrastre.

\section{INTRODUCTION}

Measuring the biological and economic impacts of management measures adopted in fisheries is an important objective for policy makers to ensure the sustainability of the activity. Maximising the amount of stock harvested while ensuring a self-sustaining stock left for future harvests is not an easy task. At 
the same time it is difficult to regulate fishing effort for a series of reasons, among which (Sumaila, 1999): i) renewable resources are often "common property"; ii) different fishing vessels affect stocks differently; iii) the catch of juveniles or mature fish can have important consequences for those species which are long-lived; and iv) the capital embodied in the exploitation is often non-malleable.

Policy makers are constrained with decisions which attempt to maximise production and maintain employment today, but risk industry collapse in the near future due to fishery depletion. Measures of control are divided into two categories: input control (including exclusive areas, seasonal closing, effort allocation, etc.) and output control (concerning catches and their size and including, for instance, TACs and individual quotas). The fisheries management measures employed in the Adriatic sea are based on input control, through closed areas, closed seasons, limiting the fishing effort, and restricting the net dimensions and other fishing tools. From an economic point of view fisheries are managed through subsidies, taxes and penalties (AdriaMed, 2005). Sardine (Sardina pilchardus) and anchovy (Engraulis encrasicolus) are the most important species of small pelagic stocks within the Adriatic Sea (Santojanni et al., 2003; 2005). Small pelagic fisheries play significant economic and social roles in the total value of catches and the number of fishermen employed within the industry. These two small pelagic species have shown important fluctuations in abundance over the last 30 years in the northern and central Adriatic Sea (area 17 of the General Fisheries Commission for the Mediterranean), with a near-collapse of the anchovy stock in the late 1980s (Santojanni et al., 2003; 2007a) and a steady decline of the sardine stock in recent years (Santojanni et al., 2005; 2007b). Although large fluctuations of small pelagics stocks are well-known and environmentally-driven in many cases (Patterson, 1992; Cushing, 1996), in the case of anchovy and sardine of the northern and central Adriatic, the values of fishing mortality were outside precautionary levels, coinciding with the periods of near-collapse of stocks (Santojanni et al., 2007a, b).

In previous years there have been decreases in pelagic catches, demersal resources, and the number of vessels, operators and operation hours in the northern Adriatic sea (Ungaro et al., 2001; Cingolani et $a l ., 2004 \mathrm{a}, \mathrm{b})$. The size of the fleet was reduced by about 22\% between 2002 and 2005. Decreases in participation within this sector are principally due to high operation costs and deflated market prices; furthermore, from the demand side they are linked to the reduction of wholesale and retail consumption, attributable to high prices. This produces a cutback in the net contribution margin for every kilogram of captured and/or commercialised product. Another factor is the reduction of the competitiveness linked to the opening of larger markets. In order to maintain the sustainability of these important fisheries, it is imperative to minimise these constraints through processes of adding product value (promotion, quality certification, etc.).

Successful fishery management must take into account both biological and economic aspects. For this reason, bioeconomic models are employed to provide directions for fishery management (Defeo and Seijo, 1999; Ulrich et al., 2002; Lleonart et al., 2003; Maynou et al., 2006; Mattos et al., 2006). These tools quantify the effects arising from the application of specific management measures to particular stocks, to simulate different scenarios and to obtain an evaluation of risks associated with different levels of resource exploitation.

The model applied here, MEFISTO (Mediterranean Fisheries Management Tools, Lleonart et al., 2003), was developed specifically for Mediterranean Sea fisheries. Before employing this model, it is important to understand fishing fleet dynamics and the main characteristics of the model that allow its application to fishery of small pelagics in the northern Adriatic sea.

The MEFISTO model has been previously applied to a case study of hake in Catalonia (western Mediterranean), as shown in Lleonart et al. (2003), but it was later applied to red shrimp (Aristeus antennatus) fisheries in the Catalan sea (Maynou et al., 2006) and to carry out an analysis of hand-line and gillnet coastal fisheries of Pernambuco State (Mattos et al., 2006).

According to Martín (1991), the fishing activity in the Mediterranean is characterised by a wide diversity of exploited species and fishing technology, as well as by the seasonal variations of the catches, which are relatively small compared to large-scale Atlantic fisheries. With non-industrial fisheries, where catches are marketed fresh locally, fleets work five days a week and return to port every day. Seasonal activity of the fleet is related to the ecology of the different species, meteorological conditions, and tourist seasons. Labour relationships are based 
on a share system, not on fixed salaries. All these ecological, economic and structural similarities justify the application of the MEFISTO model to the Adriatic fisheries.

The objectives of this work were to analyze the potential effects of different management regimes on small pelagic fisheries based on a bioeconomic simulation model disaggregated at the vessel level, and to examine the trends in biological and economic indicators for the markets of the Veneto region located in the northern Adriatic Sea (Fig. 1).

\section{MATERIAL AND METHODS}

Bioeconomic analysis of small pelagic fisheries which occur in the Veneto Region (northern Adriatic sea) is used to simulate the consequences that various management measures can have on this sector. The sampling ports were Caorle, Venice, Chioggia, Porto Viro, Pils and Scardovari. Pelagic fishing is performed with a volante vessel (mid-water pair trawl).

The volante is towed by two fishing boats working in a pair and holding a tow-line, each one tethered to the head rope and the other one to the foot rope. Volante vessels generally fish by daylight, and land their catches every evening. Each fishing trip lasts around 11-15 hours. Boats leave the harbour from 2.30-3.30 a.m. and return between 11.00 a.m. and 7.00 p.m., depending on the success of the fishing day. The working week is from Monday to Friday (Commission of the European Communities, 2004). Sardines and anchovies captured by Veneto fishermen are commercialised at six local markets. Part of these products does not pass through markets because it is withdrawn by the local producers' organisation in order to maintain the price at a certain level.

Twenty-one pairs of volante fishing vessels operate usually within this area, with an average engine power of $470 \mathrm{HP}$ and an average size of 88 GRT, but there are wide variations in both size and engine power. In this study we divided the fleet into 4 classes according to vessel size, including vessels of 12 GRT as well as vessels of 200 GRT. The classes are labelled as: Volante 1, Volante 2, Volante 3 and Volante 4 . The division of the fleet into four classes allows us to assign each group a different catchability level.

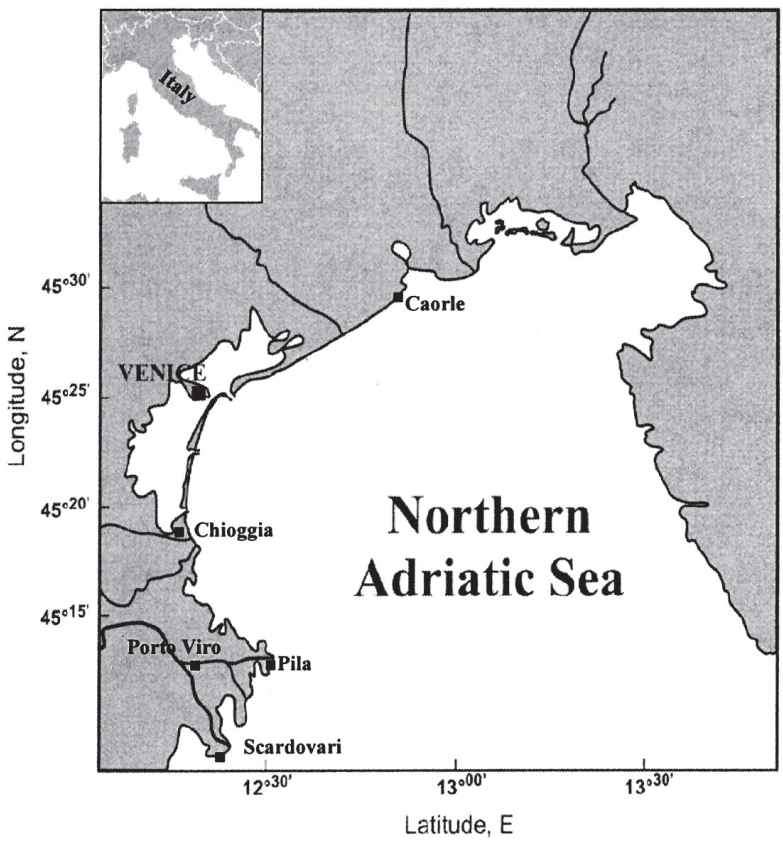

FIG. 1. - Map of the study area, showing the location of the markets analysed in the Veneto region, northeastern Italy.

Each vessel class was allocated a specific catchability value, based on its relative catch efficiency as given by its specific GT. Catchability was expressed as function of the GT: for each class of vessels, we obtained the average value of GT. A catchability value equal to 1 was assigned to a vessel with a GT corresponding to the average, and the catchability value of the other vessels in the class was scaled on the basis of the deviation of their GT from the average. Assuming a relative catchability of 1 for the smallest-sized fleet (Volante 1), the catchabilities of the other fleets were: Volante 2, $\mathrm{q}=1.006$; Volante 3, $\mathrm{q}=1.007$; and Volante 4, $\mathrm{q}=1.023$. It is apparent that vessels of Volante 4, which are larger and equipped with better technology, have a higher fishing power than those of the other three fleets.

In 2004 the total catch of small pelagic fish in the Veneto region amounted to $12400 \mathrm{t}$, corresponding to $41 \%$ of the total regional production, of which 1300 tonnes were sardine and 11 130 tonnes were anchovy.

The target species of the mid-water trawl are mainly sardine (Sardina pilchardus) and anchovy (Engraulis encrasicolus); other mid-water species targeted are mackerel (Scomber spp.), sprat (Sprattus sprattus) and horse mackerel (Trachurus spp.). Fishing for other pelagics and also "white fish" (Sparidae, Mugilidae, Merlangus merlangus, etc.) takes place occasionally 
and opportunistically, but it is considered rather rare (Santojanni et al., 2005).

The bioeconomic model called MEFISTO is a multispecies, multifleet and multigear simulation model described in detail in Lleonart et al. (1999, 2003). Starting from an initial condition, the simulation model incorporates the trajectory of resources and fishing fleets, disaggregated by vessels or homogeneous vessel classes, and computes the most probable future trajectory when some parameters in the model are changed, simulating management actions. This model is a dynamic model built on three modules or boxes: a stock box, a market box and a fisherman box.

The stock module simulates resource dynamics in the sea, from reproduction to growth and death, and considers two kinds of species: the main species, whose dynamics are completely known (and modelled through an age-structure biological model), and the secondary species, whose dynamics are not known but their catch is empirically related to the catch of the main species. In this study we consider only two main species; other secondary species are not included due to low relevance in terms of catches and value. Model inputs are fishing effort and catchability (derived from the fisherman box), whose product represents the fishing mortality applied to the stock. Outputs are fish catches that are converted to revenues by means of species-specific price equations.

The von Bertalanffy growth parameters, length-weight relationship parameters, maturity ratio and natural mortality $(M)$ were taken or derived from information on the FishBase website (http://www.fishbase.org/home.htm) and from literature sources (Sinovčić, 1984, 1986, 2000; Santojanni et al., 2003). The necessary information on the population structure concerning the number of individuals, fishing mortality $(F)$ and number of recruits $(R)$ were estimated by means of virtual population analysis using the VIT program (Lleonart and Salat, 1997). Table 1 shows the growth parameters of the von Bertalanffy growth function $\left(L_{\infty}, k\right.$ and $\left.t\right)$ established for sardine and anchovy, as well as the parameters of length-weight relationship ( $a$ and $b$ ) and the summary of the results of a standard VPA that was run with the VIT program. This permitted us to define the initial recruitment, the mean stock biomass (Bmean) and the spawning stock
TABLE 1. - Biological parameters of Sardina pilchardus and Engraulis encrasicolus exploited in the northern Adriatic sea. Parameters of the von Bertalanffy growth function: $L_{\infty}, k$ and $t_{0}$; length-weight relationship: $a, b$; natural mortality $(M)$, spawning stock biomass (SSB), mean stock biomass (Bmean), initial recruitment and average fishing mortality (F). Source: www.fishbase.org, Sinovčić (1984, 1986, 2000), Santojanni et al. (2003) and own results.

\begin{tabular}{|c|c|c|}
\hline Parameters & sardine & anchovy \\
\hline$L_{\infty}(\mathrm{cm})$ & 21.19 & 19.40 \\
\hline$k\left(\right.$ year $\left.^{-1}\right)$ & 0.35 & 0.570 \\
\hline$t_{0}$ (year) & -2.42 & -0.50 \\
\hline$a\left(\right.$ length-weigth relationship $\left.\mathrm{w}=\mathrm{a} \cdot \mathrm{l}^{\mathrm{b}}\right)$ & 0.069 & 0.0116 \\
\hline$b$ (length-weigth relationship $\mathrm{w}=\mathrm{a} \cdot \mathrm{l}^{\mathrm{b}}$ ) & 3.050 & 2.782 \\
\hline Natural mortality (M) $\left(\right.$ year $\left.^{-1}\right)$ & 0.5 & 0.600 \\
\hline SSB (thousand t) & 3.75 & 30.95 \\
\hline Bmean (thousand t) & 7.07 & 60.54 \\
\hline Recruitment (x $10^{6}$ ind.) & 298.56 & 3281.52 \\
\hline $\begin{array}{l}\text { Unweighted mean fishing mortality } \\
\text { (F) }\left(\text { year }^{-1}\right)\end{array}$ & $\begin{array}{l}\text { ages } 0-5 \text { : } \\
0.464\end{array}$ & $\begin{array}{l}\text { ages } 0-4 \text { : } \\
0.308\end{array}$ \\
\hline
\end{tabular}

biomass (SSB) of the two species considered. To simplify the application of the model and to avoid accounting for the large natural fluctuations observed for these species, we assumed recruitment to be independent of the parental stock and to fluctuate randomly around the values observed in 2004, following a lognormal of mean $R$ with a standard deviation of 0.1 . This ensures a moderate variation of $c a .15 \%$ in recruitment from year to year.

Data concerning catches are not official but real data, in the sense that we took into account the quantity commercialised not only in the market but also through the organisations of producers. Part of the product is withdrawn from the market by the organisation of producers in order to control supply and consequently prices, and is directly sold to the processing industries.

The market box converts the fish catches of each species generated by the stock model into money, through price functions. In terms of market price, sardine is considerably more valuable than anchovy, because sardine is required above all for the processing industry. In 2004 the average sale price of for the markets of the Veneto region amounted to $0.852 € / \mathrm{kg}$ for anchovy and $1.727 € / \mathrm{kg}$ for sardine (data token from the six local Veneto fish markets).

The reference price was estimated as average price of the six fish markets of the Veneto region. The fisherman box simulates the fishermen's economic behaviour and decisions. Based on money generated in the market module, fishermen can increase the capital invested in fishing. The outputs 
are effort (within a system where maximum effort is established by law) and catchability, which the fishermen can affect by investing capital in the vessels. The dynamics of catchability $\left(\mathrm{q}_{\mathrm{t}, \mathrm{v}}\right)$ of each vessel were modelled by considering a conservative interannual $1 \%(\tau)$ increase in fishing power (Eide et al., 2003) related to the increase in investment of the vessels:

$$
\mathrm{q}_{\mathrm{t}, \mathrm{v}}=\tau^{\mathrm{t}} \mathrm{q}_{\mathrm{t}-1, \mathrm{v}}
$$

The value of $\tau$ chosen is within the lower values reported in the literature for other fisheries (e.g. 2-3\% in Lindeb $\varnothing, 2001$; or 1-4\% in Philips and MelvilleSmith, 2005).

At the next iteration of the simulation the fishing mortality applied by the fleet to each cohort will be the product of the total catchability, fishing effort, and selectivity.

Discarding does not occur in relevant quantities, as declared by the operators and confirmed in Santojanni et al. (2005), so fishing mortality due to discards was not included in the model.

Almost no previous data on costs and revenues were available for these fleets, and the data presented here were obtained from interviews carried out in the 6 sampling ports (Table 2).

We interviewed the crew belonging to the representative vessels of each of the four classes. In total we interviewed nine pairs of vessels divided in this way: two belonging to fleet 1 , eight to fleet 2, six to fleet 3 and two to fleet 4 . Simulations were run at the basic time unit of 1 year for a projection horizon of 10 years, using 2004 as the reference year, and the number of stochastic iterations for each simulation run was 1000. The results are presented as the median value of the simulation runs. Five scenarios are presented, simulating a set of four alternative management measures against the status quo (scenario 0). The events are introduced in the third year of the simulation.

Scenario 0 was the base scenario, simulating the probable development of the fishery if no management action was taken.

Scenario 1 simulated the increase in the fuel price by a factor of: $10 \%, 20 \%, 30 \%$ and $40 \%$, resulting in an increase in the costs of the fishing effort. The tax exemption of the fuel price currently amounted to $84 \%$ of the price of fuel, but we did not consider the option of removing the tax exemption because it turned out to be unsustainable for about $86 \%$ of the volante vessels.

Scenario 2 simulated the reduction in the fuel price by a factor of $20 \%$, resulting in a decrease in the costs of the fishing (the fuel cost represents the first cost item, amounting to about $80 \%$ of the total variable common costs).

Scenario 3 simulated a restriction on number of the days at sea, assessing the impact of management measures aimed at limiting the effort with respect to current levels. The effort hypoth-

TABLE 2. - Initial conditions for the economic, technical and market parameters of volante fishing vessels operating in the Veneto region, northeastern Italy (average values per vessel class).

\begin{tabular}{|c|c|c|c|c|}
\hline Cost structure of the fleet & Volante 1 & Volante 2 & Volante 3 & Volante 4 \\
\hline Capital in €/vessel & 156848 & 449085 & 761291 & 1211304 \\
\hline Annual costs in $€ /$ vessel & 17376 & 25881 & 37090 & 45270 \\
\hline Commercial costs in $\%$ & 9 & 9 & 9 & 9 \\
\hline Owner's share in \% & 50 & 50 & 50 & 50 \\
\hline Daily fuel consumption in litres/vessel & 269 & 617 & 733 & 1.071 \\
\hline Daily ice expenses in $€ /$ day & 17 & 34 & 41 & 48 \\
\hline Demolition, sale, transfer €/GRT & 4228 & 3011 & 2732 & 2732 \\
\hline \multicolumn{5}{|l|}{ Technical structure of the fleets } \\
\hline GRT/vessel & 10 & 59 & 112 & 178 \\
\hline $\mathrm{HP} / \mathrm{vessel}$ & 178.3 & 419.0 & 533.8 & 681.0 \\
\hline Crew/vessel & 3 & 5 & 6 & 7 \\
\hline Daily fishing hours & 13 & 13 & 13 & 13 \\
\hline Annual fishing days & 225 & 225 & 225 & 225 \\
\hline Number of vessels & 6 & 18 & 12 & 6 \\
\hline \multicolumn{5}{|l|}{ Market } \\
\hline Sardine price in $€ / \mathrm{kg}$ & 1.727 & 1.727 & 1.727 & 1.727 \\
\hline Anchovy price in $€ / \mathrm{kg}$ & 0.952 & 0.952 & 0.952 & 0.952 \\
\hline \multicolumn{5}{|l|}{ Other economic factors } \\
\hline Opportunity cost in \% & 2 & 2 & 2 & 2 \\
\hline Financial cost in $\%$ & 5 & 5 & 5 & 5 \\
\hline Fuel price in $€ /$ litre & 0.510 & 0.510 & 0.510 & 0.510 \\
\hline
\end{tabular}



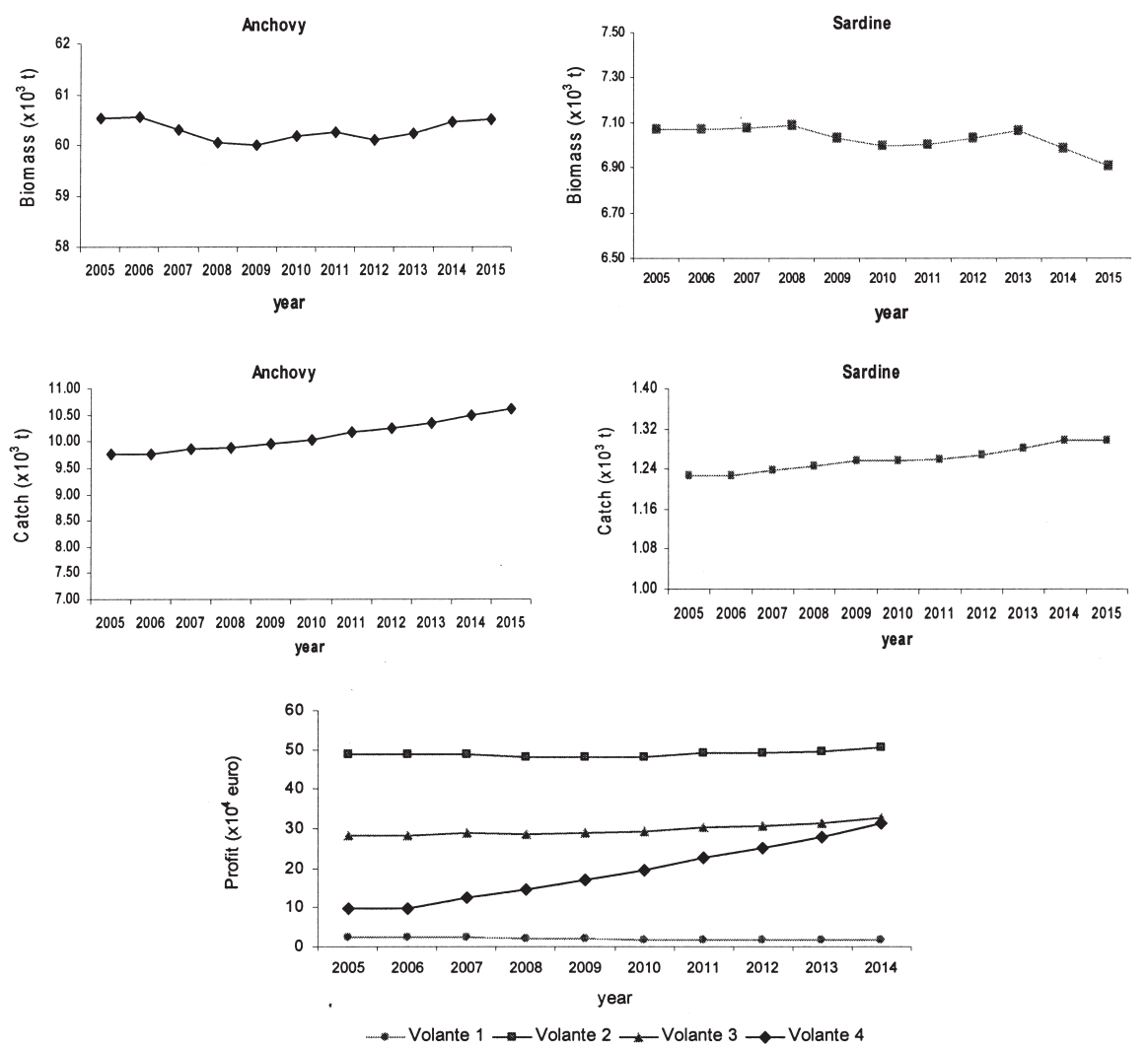

FIG. 2. - Bioeconomic simulations for volante vessels in a 10 years projection. Lines represent the median of 1000 simulations.

eses in terms of number of days at sea were 185 , 205 and 215 days.

Scenario 4 simulated the extension of the fishing period up to a maximum of 235 and 245 days.

\section{RESULTS}

In addition to current management, corresponding to scenario 0 and no change in the status quo of 2004 (Fig. 2), we evaluated 4 management strategies for the four classes of vessels and for the two species considered. We compare the performance of the four strategies using 4 indicators: catch, profits, recruitment, and total biomass. The results of the simulations defined are presented separately for the two stocks considered and for the four vessel classes into which the fleet was divided (Fig. 3 and 4).

According to the hypothesis of the model, the "status quo" condition and the scenarios are characterised by increasing temporal catchability $(\tau=$ $1 \%$ annually) and different base catchabilities $\left(\mathrm{q}_{0}\right.$ for each fleet). As a consequence of this, fishing mortality increases over time due to increasing $\mathrm{q}$ and different fleets apply different fishing mortalities.
The base scenario (Scenario 0, Fig. 2) shows a relatively stable biomass trajectory for both species, under the hypothesis of constant stochastic recruitment. Total catches increase slightly from a production of $11300 \mathrm{t}$ in 2004 to around 11800 $\mathrm{t}$ at the end of the simulation run (mainly due to anchovy increase), as a consequence of fishing mortality increase due mainly to increasing catchability of segment 4 (Fig. 2, right panel). Catches per fleet (not shown) increase slightly for each fleet, resulting in increased revenues, especially for fleet 4 . In the case of fleet 4 , the practically constant costs during the simulation horizon and the increasing catches result in a 3 -fold increase in profits (from ca. 100 to 300 $\mathrm{k} €$ annually), this is due to the higher catches of volante 4 because of higher fishing mortality (due to higher initial $q$ and the increasing trend in $q$ ), and to the better profitability of this fleet, due to the practically constant costs.

The catch and biomass trajectories are not heavily affected as a consequence of the change in fuel price (Scenarios 1 and 2, Fig. 3, top): neither increasing $(0.55,0.60,0.65$ and $0.70 € / 1)$ nor decreasing $(0.40 € / 1)$ fuel prices would be sufficient to reduce 

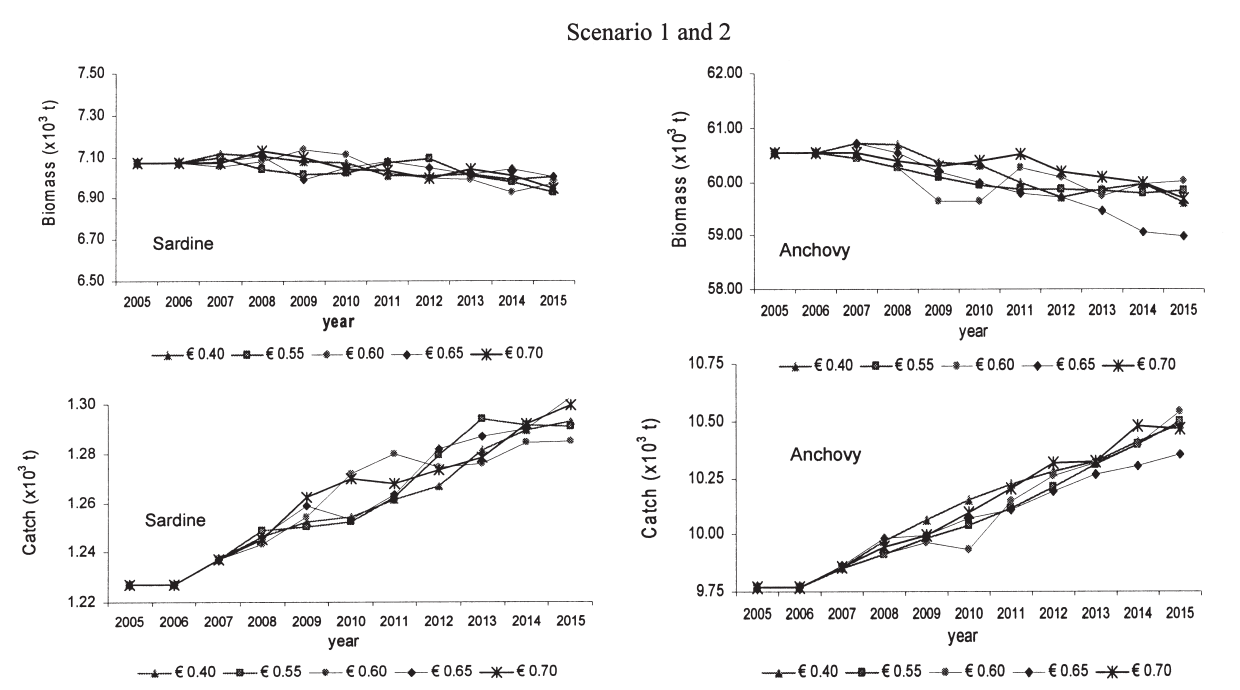

Scenario 3 and 4
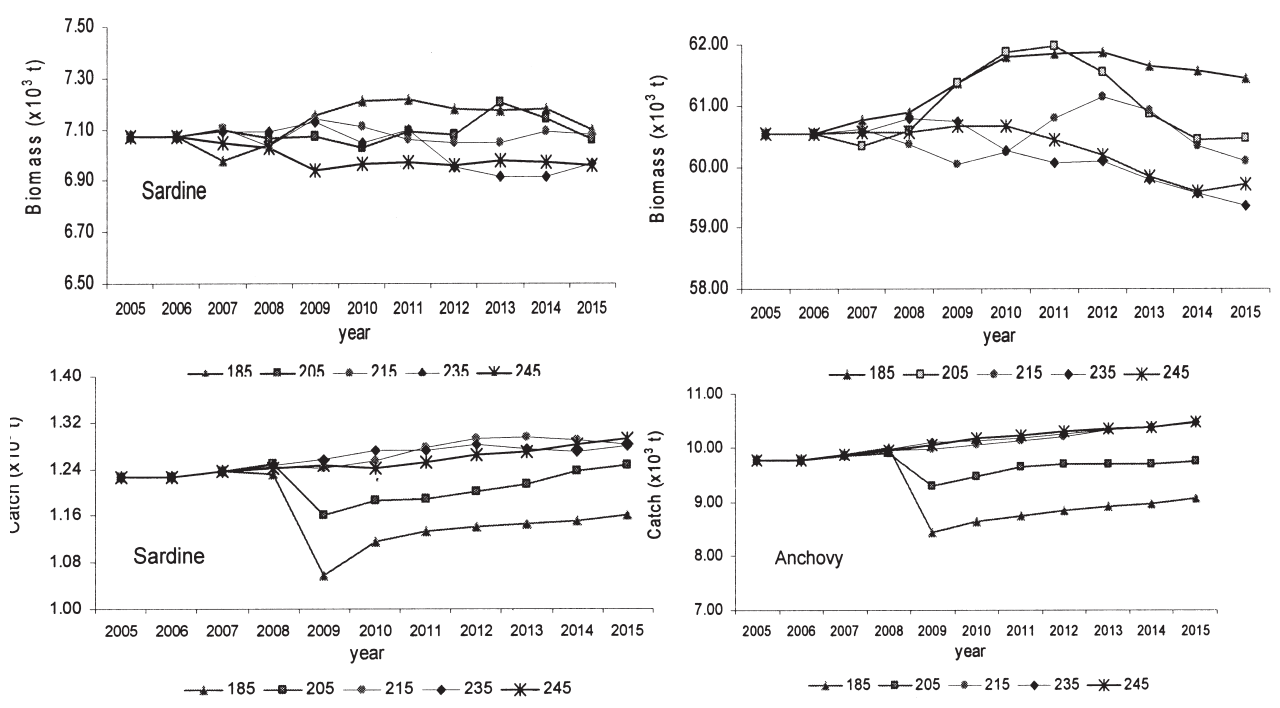

FIG. 3. - Bioeconomic simulations for sardines and anchovies stocks in a 10 years projection. Lines represent the median of 1000 simulations. Scenario 1: increase in fuel price $(0.55$ to $0.70 € / 1)$; Scenario 2: decrease in fuel price $(0.40 € / 1)$; Scenario 3: effort reduction (185 to 215 days); Scenario 4: effort increase (235 and 245 days).

increasing fishing mortality (due to the temporal increase in catchability) and increased catches, resulting in a slight decrease in biomass of both species at the end of the simulation run.

The results in scenarios 1 and 2 (Fig 3) should be interpreted in the light of constant recruitment and $\mathrm{F}<\mathrm{M}$ for both stocks. This means that the predicted stock dynamics are not heavily affected by variations in fuel prices because effort will not change (i.e. increasing fuel price is not sufficient to withdraw effort from the fleet). Only the overall trends of increasing catches and slightly decreasing biomass, already noted for Scenario 0, are noticeable, because of temporally increasing q. Instead, variation in fuel prices has direct impacts on the profitability of the 4 fleets, because fuel cost is a sizeable amount of the total costs.

The trajectories observed for biomass and catches in Figure 2 (top) are due to the relative profitability of the 4 fleet segments: profits decrease for Volante 1 after 2008 (and become negative for high fuel prices after 2008 and 2012 for 0.70 and $0.65 € / l$, respectively) but profits remain relatively stable for Volante 2 and 3 through the simulation run, and actually increase for Volante 4 (Fig. 4, top).

The increase and decrease in profits for each fleet segment result in a non-homogeneous response to fuel price increase across the fleet. In particular smaller vessels (Volante 1) are more sensitive to changes and for this fleet a price increase of $30-40 \%$ 

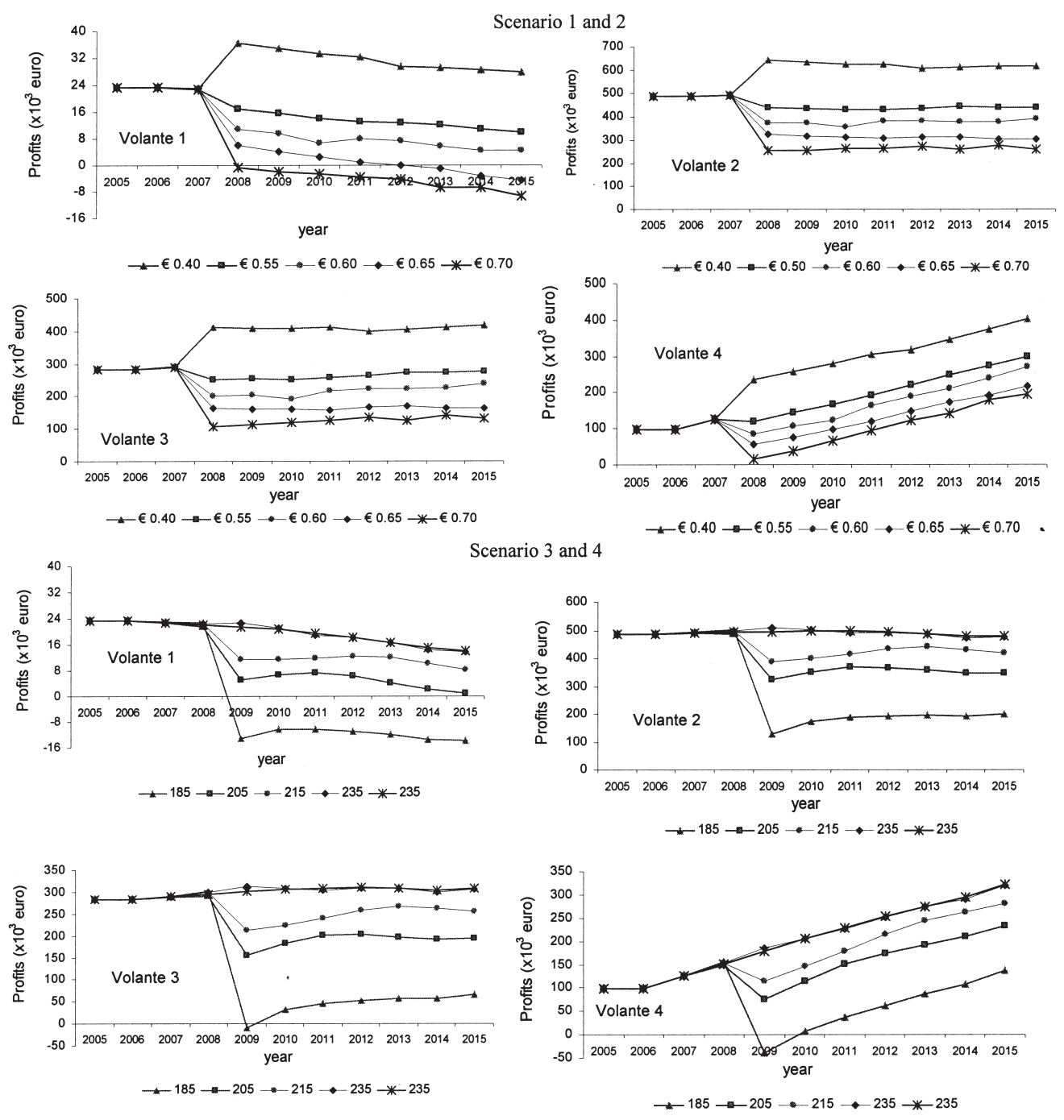

FIG. 4. - Bioeconomic simulations of profits for volante vessels in a 10-year projection. Lines represent the median of 1000 simulations. Scenario 1: increase in fuel price $(0.55$ to $0.70 € / 1)$; Scenario 2: decrease in fuel price $(0.40 € / 1)$; Scenario 3: effort reduction (185 to 215 days); Scenario 4: effort increase (235 and 245 days).

would determine in the long run situations of negative profits.

In fact, a higher number of days at sea (effort increase) corresponds in general to higher costs but directly influences the fishing mortality allowing the level of the catches to be increased. The results in Figure 4 (lower) show the relative profitability of each fleet.

Regarding the modification of the maximum number of days at sea (Scenario 3: 185, 205 and 215 days, and Scenario 4: 235 and 245 days), our results (Fig. 3, bottom) show that in the short run anchovy biomass would derive a benefit from the reduction of the number of days at sea (Scenario 3: 185 and 205 days). In the long run, values of anchovy biomass higher than present-day levels would only be sustained by setting the maximum number of fish- ing days at 185 . For the sardine stock also, only a sharp reduction in the number of days (Scenario 3: 185 days, Fig. 3, top) can bring a benefit. As the number of days is reduced the volume of catches would decrease in the short term, but increase in the long run, although always at levels below current levels (Fig. 3). Smaller profits would be generated, in correspondence to the smaller number of days at sea and reduced catches (Fig. 4, bottom), seriously compromising the profitability of the fleet, especially for the small vessel segment (Volante 1). For vessel groups 2 and 3 profits would remain positive also under Scenario 3 (effort reduction), but all vessel groups would sustain major short-term losses. Effort reduction would actually benefit only Volante 4 (the large vessel segment) in the long run. 


\section{DISCUSSION}

The MEFISTO bioeconomic model was successfully applied to the small pelagic fishery in the northern Adriatic Sea. The model was used to quantify the effects arising from the application of management measures and to simulate scenarios providing a risk assessment associated with different levels of exploitation of the resources. In these terms this is a cause-effect model that can support the policy-maker in the decision process. With this aim, for example, it shows that the adjustment should be done by segmenting the fleet. The impact of each measure produces different results depending on the size of the vessels to which it is applied.

This work represents one of the first applications of bioeconomic simulation tools to small pelagic fisheries in the northern Adriatic Sea. Other bioeconomic models developed at national level, such as the BIRDMOD model (IREPA, 2005; Accadia and Spagnolo, 2006) which, however, was applied to study demersal resources, are optimisation models. The choice of different scenarios is based on the observation of catch trends and research conducted on the sector, which highlight an overexploitation of the fish resources, in particular of sardines, and a reduction in the number of vessels and operators. This means that the effort is excessive or the size of the individuals caught is too low, or both; from an economic point of view there is an increasing incapacity on the part of the operators to support the management costs of the activity. For this reason, our simulations mainly regard management aspects based on effort control whose regulation allows pressure on the overexploited stocks to be reduced so as to guarantee their conservation and jobs, safeguarding the investment made in the sector. To meet these objectives we studied the effects of different fuel prices and an alternative number of days at sea.

As stated above, fishermen buy fuel at a subsidised price, so the fiscal burden cannot be further reduced. Total production costs are also high, while producer's prices are maintained stable.

An increase in fuel price, Scenario 1, simulating the partial or total payment of removed taxes, shows that if fishers are constrained to buy fuel at a nonsubsidised price, this can have a negative impact on the fleet that may lead smaller vessels to leave the fishery. Considering the current worldwide increase in fuel prices, the economic losses sustained by smaller vessels will probably worsen in the near future.

Government subsidies, as simulated in Scenario 2 , showed that profits increase significantly. As indicated in Mackinson et al. (1997), according to a bioeconomic analysis that considers a constant CPUE model, when fishers fail to cooperate or there are subsidies, profits accrue so quickly for fishers that they continue to invest in fishing even when a stock collapse is imminent. As a consequence of this, greater catches of fish despite the decline in abundance and stock collapse are probable. The cause of this, as highlighted in Pereiro (1995), is that moderate increases in fishing mortality would lead to a small reduction in biomass and CPUE, but this is not detectable in the short term with the tools available to measure them, especially when these reductions can be masked by natural fluctuations of recruitment and natural mortality. The opposite would occur with moderate reductions in fishing mortality, and, in both cases, it would not be possible to see in the short term the beneficial consequences of moderate reductions in effort. On the other hand, generally, the more the price of fuel increases, the more the catch decreases, according to the higher costs that the fishermen would have to support in order to move theirs boats. From a biological point of view, a lower cost of the fuel leads to an increase in the fishing effort and to a reduction in the biomass. The price of fuel cannot be reduced excessively from the current (2004) price of about $0.51 € / 1$.

Temporary closure (Scenario 3 ) of fishing seems quite effective only from a biological point of view, because it allows biomass to recover, but it can also cause economic problems due to low profit levels. In particular, reducing the number of days to 185 cannot be suggested for the smaller vessels. From the bioeconomic point of view it would be better to maintain fishing effort at the current levels in terms of number of days at sea. Also, reducing the number of days to 205 might be applied without damaging biomass, but in the long term, it can lead to negative profits for the smaller vessels. Reducing the number of days to 215 would decrease profits by about $20 \%$. On the other hand, increasing the number of days to 245 (Scenario 4) would also decrease profits, although only by about $6 \%$. Profits would remain at a lower level in the case of 185 days per year, and do not reach their maximum value at 245 days per year, but rather at 225 days per year. Fishing effort higher than the current levels, and equal to 235 and 
245 days, would represent an unfavourable situation for the conservation of the stocks. We agree with the recommendations of the Scientific Advisory Committee of the GFCM that fishing effort should not increase for small pelagics stocks in GSA 17 (Santojanni et al., 2007a, 2007b).

On the basis of the bioeconomic results obtained here, the proposal for management of small pelagics fisheries in the northern Adriatic is articulated around a combination of measures: i) applying a targeted support policy in defence of smaller vessels, and in particular introducing a compensatory policy; ii) guaranteeing greater profits for the sector by means of cost reduction or/and value added policies (promotion, labelling, etc); iii) promoting sector restructuring (commerce, aquaculture, tourism, etc); iv) placing fishing effort in terms of maximum number of days at sea at between 205 and 215 days per year.

\section{REFERENCES}

Accadia, P. and M. Spagnolo. - 2006. A bio-economic simulation model for the Italian fisheries. $13^{\text {th }}$ IIFET Conference: "Rebuilding Fisheries in an Uncertain Environment", Portsmouth, UK, 11-14 July 2006.

AdriaMed. - 2005. General outline of marine capture fisheries legislation and regulations in the Adriatic Sea countries. FAO-MiPAF Scientific Cooperation to Support Responsible Fisheries in the Adriatic Sea. GCP/RER/010/ITA/TD14 (rev. 1). AdriaMed Tech. Docs., 14 (rev. 1).

Cingolani, N., A. Santojanni, E. Arneri, A. Berlardinelli, S. Colella, F. Donato, G. Giannetti, G. Sinovčić and B. Zorica. - 2004a. Anchovy (Engraulis encrasicolus, L.) stock assessment in the Adriatic Sea: 1975-2003. FAO-MiPAF Scientific Cooperation to Support Responsible Fisheries in the Adriatic Sea, GCP/RER/010/ITA/OP-14.

Cingolani, N., A. Santojanni, E. Arneri, A. Berlardinelli, S. Colella, F. Donato, G. Giannetti, G. Sinovčić and B. Zorica. - 2004b. Sardine (Sardina pilchardus, Walb.) stock assessment in the Adriatic Sea: 1975-2003. FAO-MiPAF Scientific Cooperation to Support Responsible Fisheries in the Adriatic Sea, GCP/RER/010/ITA/OP-13.

Commission of the European Communities. - 2004. European Union Mediterranean Fisheries and exploited resources, Rep. $\mathrm{N}^{\circ} 772$.

Cushing, D.H. - 1996. Towards a science of recruitment in fish populations. Ecology Institute, Oldendorf/Luhe, Germany.

Defeo, O. and J.C. Seijo - 1999. Yield-mortality models: a precautionary bioeconomic approach. Fish. Res., 40: 7-16.

Eide, A., F. Skjold, F. Olsen and O. Flaaten. - 2003. Harvest functions: The Norwegian bottom trawl cod fisheries. Mar. Res. Econ., 18: 81-93.

IREPA. - 2005. A working proposal for the economic and biological data collection of the small scale fisheries. Workshop on Small Scale Fisheries. Kavala, Greece $12^{\text {th }}-16^{\text {th }}$ September 2005.

Lindeb $\varnothing$, E. - 2001. Technological progress and capacity estimations. Management implications for the Danish cod trawl fishery. Mimeo.

Lleonart, J. and J. Salat. - 1997. VIT: Software for fishery analysis. User's manual. FAO Computerized Information Series, Fisheries. Vol. 11.

Lleonart, J., F. Maynou and R. Franquesa. - 1999. A bio-economic model for Mediterranean fisheries. Fish. Econ. Newsletter, 48: $1-16$.

Lleonart, J., F. Maynou, L. Recasens and R. Franquesa. - 2003. A bio-economic model for Mediterranean fisheries, the hake off Catalonia (western Mediterranean) as a case study. Sci. Mar., 67(Suppl. 1): 337-351.

Mackinson, S., U.R. Sumaila and T.J. Pitcher. - 1997. Bioeconomics and catchability: fish and fishers behaviour during stock collapse. Fish. Res., 31: 11-17.

Martín, P. - 1991. La pesca en Cataluña y Valencia (NO Mediterraneo): análisis de las series históricas de captura y esfuerzo. Inf. Téc. Sci. Mar., 162.

Mattos, S., F. Maynou and R. Franquesa. - 2006. A bio-economic analysis of the hand-line and gillnet coastal fisheries of Pernambuco State, north-eastern Brazil. Sci. Mar., 70(2): 335-346.

Maynou, F., F. Sardà, S. Tudela and M. Demestre. - 2006. Management strategies for red shrimp (Aristeus antennatus) fisheries in the Catalan sea (NW Mediterranean) based on bioeconomic simulation analysis. Aquat. Liv. Res., 19: 161-171.

Patterson, K. - 1992. Fisheries for small pelagic species: an empirical approach to management targets. Rev. Fish Biol Fish., 2: 321-338.

Pereiro, J.A. - 1995. Assessment and management of fish populations: a critical view. Sci. Mar., 59(3-4): 653-660.

Philips, B.F. and R. Melville-Smith. - 2005. Sustainability of the western rock lobster fishery: A review of past progress and future challenges. Bull. Mar. Sci., 76: 485-500.

Santojanni, A., E. Arneri, C. Barry, A. Belardinelli, N. Cingolani, G. Giannetti and G. Kirkwood. - 2003. Trends of anchovy (Engraulis encrasicolus, L.) biomass in the northern and central Adriatic Sea. Sci. Mar., 67(3): 327-340.

Santojanni, A., N. Cingolani, E. Arneri, G. Kirkwood, A. Belardinelli, G. Giannetti, S. Colella, F. Donato and C. Barry. - 2005. Stock assessment of sardine (Sardina pilchardus, Walb.) in the Adriatic Sea, with an estimate of discard. Sci. Mar., 69(4): 603-617.

Santojanni, A., N. Cingolani, E. Arneri, A. Belardinelli, S. Colella, F. Donato, G. Giannetti, I. Leonori, A. De Felice, G. Sinovčić and B. Marceta. - 2007a. Anchovy (Engraulis encrasicolus, L.) stock assessment in the Adriatic sea: 1975-2006. Working Group on Small Pelagics, Doc No 11, Athens 10-14 September 2007, GFCM SAC Subcommittee on Stock Assessment. http:// www.icm.csic.es/rec/projectes/scsa/Small_pelagics_2007/

Santojanni, A., N. Cingolani, E. Arneri, A. Belardinelli, S. Colella, F. Donato, G. Giannetti, I. Leonori, A. De Felice, G. Sinovčić and B. Marceta. - 2007b. Sardine (Sardina pilchardus, Walb.) stock assessment in the Adriatic sea: 1975-2006. Working Group on Small Pelagics, Doc No 12, Athens 10-14 September 2007, GFCM SAC Subcommittee on Stock Assessment. http:// www.icm.csic.es/rec/projectes/scsa/Small_pelagics_2007/

Sinovčić, G. - 1984. Summary of biological parameters of sardine (Sardina pilchardus Walb.) from the Central Adriatic. FAO Fish. Rep., 290:147-148.

Sinovčić, G. - 1986. Estimation of growth, mortality, production and stock size of sardine, Sardina pilchardus (Walb.), from the middle Adriatic. Acta Adriat., 27: 67-74.

Sinovčić, G. - 2000. Anchovy, Engraulis encrasicolus (Linnaeus, 1758): biology, population dynamics and fisheries case study. Acta Adriat., 41(1): 3-53.

Sumaila, U.R. - 1999. A review of game-theoretic models of fishing. Mar. Pol., 23(1): 1-10.

Ulrich, C., B. Le Gallic, M.R. Dunn and D. Gascuel. - 2002. A multispecies multi-fleet bioeconomic simulation model for the English Channel artisanal fisheries. Fish. Res., 58: 379-401.

Ungaro, N., N. Vrgoć and P. Mannini. - 2001. The biology and stock assessment of Merluccius merluccius (L.) in the Adriatic Sea: an historical review by geographical management units. FAO-MiPAF Scientific Cooperation to Support Responsible Fisheries in the Adriatic Sea. GCP/RER/010/ITA/OP-03.

Scient. ed.: J. Lleonart.

Received June 12, 2007. Accepted January 8, 2009.

Published online May 4, 2009. 